\title{
NEMŠKO-SLOVENSKI ZGODOVINSKI GLOSAR ALI POSKUS PISANJA GLOSARJA NA PODROČJU HUMANISTIKE OZ. DRUŽBOSLOVJA
}

\section{UVOD}

Nemško-slovenski zgodovinski glosar (Hudelja: 2010) je nastal v okviru dolgoletnega ukvarjanja s sodobnimi zgodovinskimi besedili, tako strokovnimi kot tudi znanstvenimi, študija arhivskega gradiva in prevajanja zgodovinskih tekstov iz, zlasti pa v nemški jezik. Pomeni logični zaključek predhodnih priročnikov besedilnega tipa, ki sem jih izdal za študente enopredmetne študijske smeri na Oddelku za zgodovino Filozofske fakultete Univerze v Ljubljani. Oddelek je v preteklih desetletjih pripisoval velik pomen znanju jezikov virov, t.j. nemščini in latinščini, in jima - do uvedbe bolonjskega študija - namenjal zadovoljivo število ur v 1. in 2. letniku (po 90 ur na semester). Situacija se je drastično poslabšala $z$ uvedbo bolonjske reforme, ko je del teh ur pripadel strokovnim predmetom. Nemščini je bilo dodeljeno le $60 \mathrm{oz} .75$ ur v zimskem in letnem semestru 1. letnika ter le 75 ur v zimskem semestru 2. letnika. Glede na opisano stanje in vse slabše predznanje nemškega jezika postaja očitno, da bo dosedanji cilj pouka - aktivno znanje - vse težje dosegljiv. Toda tudi pasivno znanje, torej samo razumevanje besedil - v našem primeru ne le sodobnih strokovnih besedil, temveč tudi arhivskega gradiva $z$ vsemi posebnostmi (arhaični jezik, gotica) - predstavlja za študente kar trd oreh.

\section{UPORABNIKI GLOSARJA}

Kot pomemben pripomoček pri učenju tujega jezika stroke je glosar v prvi vrsti namenjen študentom in diplomantom zgodovine, pa tudi drugih, zlasti tistih humanističnih strok, s katerimi zgodovina stopa $v$ povezavo. $V$ širšem smislu bi glosar lahko koristil vsem tistim, ki se zanimajo za domoznanstvo, krajevno zgodovino in rodoslovje. Predvidevamo lahko, da gre za izredno diferencirano skupino uporabnikov z različnim znanjem nemškega jezika in poznavanjem strokovnega področja. Najbolj neugodno razmerje med obema nedvomno obstaja pri študentih 1. in 2. letnika zgodovine, kjer je bilo na podlagi empiričnih ugotovitev (uvrstitveni testi) ugotovljeno, da je - kljub dejstvu, da se je večina brucov učila nemščine 4 leta - njihovo znanje nemškega jezika pomanjkljivo. Enako velja tudi za njihovo strokovno znanje, vendar pa je to razumljivo, saj so šele na začetku svojega strokovnega izobraževanja. 


\section{STROKOVNO PODROČJE ZGODOVINE}

Strokovno področje zgodovinske znanosti, v središču katere je človek, njegovo žitje in bitje $\mathrm{v}$ preteklosti, kaže izredno diferenciranost (kulturna, politična, gospodarska, socialna, vojaška zgodovina ...), veliko število pomožnih ved (heraldika, numizmatika, paleografija ...) in sorodnih disciplin (etnologija, sociologija, geografija ...). Za problem srednjeveških pustot se tako zanimajo zgodovinarji, geografi in arheologi, za stare zemljevide in ledinska imena zgodovinarji, geografi in slavisti, za običaje naših prednikov zgodovinarji in etnologi. Čeprav se zgodovini sorodne discipline praviloma same ukvarjajo z zgodovinskim aspektom svojega delovnega področja (pravo se npr. ukvarja s pravno zgodovino, teologija s cerkveno zgodovino), pa pomeni vzpostavljanje povezav s tistimi področji sorodnih znanosti, ki segajo v preteklost, bistvo metodičnega pristopa zgodovinske znanosti. Zgodovinski aspekti drugih znanosti pomenijo za zgodovinsko znanost le sestavne dele, ki jih le-ta vključuje in združuje v celoto zgodovinskega dogajanja.

\section{NABOR ZGODOVINSKEGA STROKOVNEGA IZRAZJA}

Nemško-slovenski zgodovinski glosar je pasivni dvojezični glosar, namenjen razumevanju besedil v ciljnem, v našem primeru nemškem jeziku. Zajema osnovno strokovno besedje, s katerim se srečujejo študenti in diplomanti zgodovine. Osrednji del glosarja tvori zgodovinsko izrazje, izrazje zgodovinskega prava, terminologija političnega in upravnega področja, v skladu z zgoraj opisanim področjem zgodovinske znanosti pa sega še na številna druga področja človeškega delovanja v preteklosti. Bistveni del glosarja tvorijo t.i. citatne besede, s katerimi tukaj označujem strokovne izraze, povzete po naslednjih delih: Pravna in družbena zgodovina Slovencev I. in II. (Ljubljana, 1979, 1980), Pravna zgodovina Slovencev (Vilfan: 1961) in Priročniki in karte o organizacijski strukturi do 1918 (Žontar, ur.: 1988). Ob uvrstitvi posameznih izrazov v geslovnik za glosar je bilo potrebno upoštevati naslednja dejstva:

4.1. Sprijazniti se je bilo treba $z$ dejstvom, da slovenski enojezični razlagalni slovar za področje zgodovine še ne obstaja (pri ZRC SAZU nastaja Slovenski pravnozgodovinski slovar) in da strokovno izrazje posledično $\mathrm{v}$ marsikaterem primeru še ni poeenoteno (npr. Landesverwalter nastopa v strokovni literaturi kot deželni upravitelj in deželni upravnik).

4.2. V glosarju je bilo potrebno zajeti relevantno izrazje različnih obdobij (stoletij!), izrazje iz različnih z današnjega zornega kota historičnih slovarjev, ki so bili v svojem obdobju - gledano sinhrono - slovarji sodobnega jezika. Glosar naj bi nudil diahron presek treh stoletij (20., 19. in deloma 18. stoletja). Za starejša obdobja bi morali uporabniki seči po posebnih slovarjih oz. glosarjih (npr. po Lexerjevem Srednjevisokonemskem žepnem slovarju za srednji vek ali Götzejevem Zgodnjenovoveskem glosarju za 16. stoletje). 
4.3. Glosar pri zapisovanju gesel sledi pravopisnim pravilom. Gesla zato praviloma niso zapisana v obliki, v kateri se pojavljajo v virih, temveč po pravopisnih normah, ki so veljale pred uvedbo najnovejšega nemškega pravopisa (2006). Izjemo tvorijo citatne besede iz zgoraj omenjenih del in še nekatere druge besede.

4.4. Pri vključevanju terminov v geslovnik je bilo potrebno upoštevati dejstvo, da je težko začrtati mejo med zgodovinsko znanostjo in nekaterimi sorodnimi znanostmi s področja humanistike in družboslovja, pa tudi naravoslovja. Vključiti je bilo potrebno strokovno izrazje, ki je skupno več znanstvenim disciplinam. $Z$ vidika pomenskih polj je za pričujoči slovar zato značilna visoka stopnja raznovrstnosti - v loku od ožje strokovne terminologije (npr. za deželnostanovsko organizacijo) preko gospodarstva (npr. izrazi za rokodelske in obrtne dejavnosti ter industrijske veje, izrazi za rokodelske poklice), kmetijstva (npr. izrazi za kulturne rastline, obdelovalne površine, kmetijska gospodarska poslopja), meroslovnega sistema (npr. izrazi za mere in uteži), medicine (npr. izrazi za bolezni (navajane kot vzrok smrti)).

4.5. Upoštevati je bilo potrebno dejstvo, da je za strokovno izrazje na področju humanistike in družboslovja značilna nižja stopnja pojmovne abstrakcije ter večji delež splošnega in manjši odstotek strokovnega izrazja. Splošno izrazje nastopa v splošno sporazumevalni vlogi, v diferenciranem in specializiranem pomenu pa kot sestavni del jezika humanistike in družboslovja. Prav to dejstvo je narekovalo širši pristop, torej vključevanje splošnega jezika v glosar, še zlasti, ker se zgodovinska znanost, ki v veliki meri temelji na analizi in sintezi arhivskega gradiva, pri »prevajanju« »jezika virov«v »jezik zgodovine« poslužuje narativnih sredstev splošnega jezika.

4.6. Glede na delovno področje zgodovinske znanosti je bilo potrebno upoštevati široko paleto besedilnih vrst, ki jih pri rekonstrukciji preteklosti preučujejo zgodovinarji: listine, urbarji, katastrski zapisi, inventarji, zakonski teksti, poslovni spisi, uradni dopisi, časopisni članki, privatna pisma, strokovni in znanstveni zgodovinski članki itd. Čeprav so predmet zgodovinskega preučevanja, pa mnoge od naštetih besedilnih vrst po svojem izvoru bolj sodijo v področje drugih strokovnih jezikov, npr. prava, uprave, politične znanosti, literature. Tudi ta aspekt je narekoval širši pristop pri naboru gesel za naš glosar.

\section{ZNAČILNOSTI V GLOSAR VKLJUČENEGA IZRAZJA}

V skladu z zgoraj definiranim strokovnim področjem zgodovine in pisano paleto disciplin, s katerimi se zgodovina povezuje, je bilo težko zamejiti nabor gradiva. $Z$ ozirom na naslovnike glosarja sem se na koncu odločil za širši pristop v smislu Praške lingvistične šole, ki loči med »centrom in periferijo«. Takšen pristop je npr. pri opisu frazeologije nemškega sodobnega jezika uporabil Wolfgang Fleischer (1982). V našem primeru so bili v središče zgodovinskega strokovnega izrazja uvrščeni historizmi in arhaizmi, pa tudi tisto izrazje, ki si ga zgodovinska znanost zaradi prepletanja z drugimi sorodnimi disciplinami deli z le-temi (npr. Wüstung/ 
pustota, Hube/kmetija). Na obrobje sodijo mnogi splošni, npr. sorodstveni izrazi, večinoma gre za samostalnike, pa tudi glagole, npr. v t. i. funkcijskih sklopih, ki pogosto nastopajo $\mathrm{v}$ pravnih besedilih, nadalje kolokacije, ki se uporabljajo v zgodovinskem in političnem kontekstu, celo predloge, značilne za pisarniško nemščino in stalne besedne skupine, ter določene stalne predložne zveze. $V$ določenem smislu je glosar tudi učni glosar, čeprav praviloma ne nudi razlag oz. definicij pojmov. Uporabnikom namreč ponuja možnost, da ponovijo že znane in spoznajo nove pomene iztočnic, zlasti tiste, ki se pojavljajo v zgodovinskem kontekstu. Prav tako glosar ob geslih pogosto navaja primere rabe $v$ različnih kontekstih. Ker glosar ni slovar razlagalnega tipa, uporabnike glede razlag terminov s kazalko napotuje na ustrezne strani v zgoraj omenjenih treh delih.

Historizmi kot osrednji del Nemško-slovenskega zgodovinskega glosarja označujejo tiste denotate, ki danes ne obstajajo več, prav za zgodovinsko znanost pa so nepogrešljivi pri opisovanju oseb, predmetov, pojavov in odnosov v preteklosti (npr. Brückenmaut/mostnina, Kopfgeld/glavarina, Ritterschlag/povišanje v viteški stan). Historizmi so seveda sestavni del vsakega zgodovinskega terminološkega slovarja. Kljub globokim družbenim spremembam so ti izrazi ohranili svoj kulturnozgodovinski pomen in jih vključujejo tudi splošni slovarji sodobnega nemškega jezika. Historizmi izhajajo iz različnih časovnih obdobjih in zajemajo različna področja človeškega delovanja v preteklosti, npr. fevdalne odnose (Lehen/fevd, Faustrecht/pravica močnejšega, Aufgebot zu Roß/poziv fevdalne konjenice), stare rokodelske poklice (Wagner/kolar, Seifensieder/milar, Dienstbote/posel), stanovsko leksiko (Verordneter/odbornik, Schirmbrief/zaščitno pismo, Gült/imenjska renta) itd.

Arhaizmi prav tako sodijo v osrednji del našega glosarja. SSKJ (1999) ta pojem natančneje opredeljuje $\mathrm{v}$ okviru časovno-frekvenčnih kvalifikatorjev kot »starinske« in »zastarele« besede. Kot »starinsko «SSKJ označuje »besedo, pomen ali zvezo, ki je bila nekoč (v kaki funkciji) splošno rabljena, danes pa ima arhaično patino «. V to skupino bi lahko uvrstili v glosar sprejete »starinske « besede Sommerfrische za današnje Ferien/počitnice, Hantieren za sodobni Handel/trgovina ali Schulmeister za današnjega Lehrer/učitelja. Takšne besede so leksikalizirane tudi v splošnih slovarjih sodobnega nemškega jezika (npr. Duden 1999). V določenih funkcijah (npr. historičnih romanih) jih avtorji uporabljajo kot stilno sredstvo za ustvarjanje historičnega kolorita, lahko pa so uporabljeni tudi ironično, npr. Schulmeister namesto Lehrer). Kot »zastarela« je v SSKJ označena »nekoč rabljena beseda, pomen ali zveza; danes pa je v knjižnem jeziku mrtva«. Naš glosar vključuje številne »zastarele« besede, npr. nemška imena za mesece: Heumonat/ Juli, Erntemonat/August, Herbstmonat/September. Tudi splošni slovarji sodobnega nemškega jezika (npr. Duden 1999) še vključujejo besedne fosile kot npr. sotan za današnji solcher/takšen, sintemal za današnji weil/ker. Le še vprašanja časa je, kdaj bodo doživeli isto usodo kot na primer besede Befreundte/sorodniki ali Schulhalter/ nemški učitelj (v Ljubljani pred uvedbo terezijanske šolske reforme), ki jih lahko najdemo le še v nemških historičnih slovarjih. Vzrokov za počasno »umiranje in izginjanje besed je veliko, v prvi vrsti velja omeniti spremenjene družbene razmere, ko poimenovanja za nekdanjo družbeno stvarnost (npr. Nemške demokratične republike) postanejo odvečna in nezanimiva, ter se - če že ne izginejo - v najboljšem primeru ohranijo le še kot historizmi. Razloge za to, da nekdaj aktualne besede 
zastarajo, je iskati tudi v tehničnem napredku: Pferdebahn/tramvaj s konjsko vprego je nadomestil Straßenbahn/električni tramvaj, Dampflokomotive/blapon je postala Lokomotive/lokomotiva na električni ali dizelski pogon. Na določenih onomasioloških področjih so nemška poimenovanja nadomestila tujke (zlasti francoskega izvora). To se je zgodilo na primer na področju železniškega prometa: Billet $\rightarrow$ Fahrkarte, Coupé $\rightarrow$ Abteil ali Perron $\rightarrow$ Bahnsteig, verjetno zaradi težje pisave francoskih tujk. Do obratnega pojava je prišlo pri zgoraj omenjenih poimenovanjih za mesece. Nemške oznake so - kljub stoletni sočasni rabi z latinskimi - končno izgubile tekmo s starejšimi rimskimi. Mogoče je vzrok za ta pojav iskati v krajših in tudi bolj natančnih tujkah. Osman (1998) navaja še mnoge druge vzroke za izginotje besed, med drugim ponesrečene nemške neologizme, ki se niso obdržali zaradi bolj jasnih, pregnantnih konkurenčnih besed (npr. Schlendergang za bolj razširjeni Spaziergang/sprehod), ponesrečeno obujanje arhaizmov, zlasti v obdobju klasicizma in romantike (npr. Werder za uveljavljeni Insel/otok), ali pa ponesrečeno uvajanje dialektizmov in evfemizmov (v našem glosarju: das Zeitliche segnen in dieser Zeitlichkeit entgehen za slov. posloviti se od tega sveta). Zanimive so tudi večpomenske besede, kjer je eden od pomenov v teku časa izginil: Gelegenheit v pomenu lega, položaj, Industrie v pomenu obrt, Volk v pomenu vojska itd.

Glosar opozarja tudi na formalne jezikovne spremembe, in sicer tako, da pri zadevnih geslih s kazalko usmerja na sodobno obliko, npr. annoch $(\rightarrow$ noch $)$. Gre za pojav jezikovne ekonomičnosti (anbeute $(\rightarrow$ beute) $)$, zamenjavo predpone $($ obn- $(\rightarrow$ un-)), številne glasovne spremembe (gulden $(\rightarrow$ golden)).

Kateri idiomatski izrazi in kako pogosto se pojavljajo v strokovnem jeziku zgodovinske znanosti, smo ugotovili z raziskavo v okviru magistrske naloge Phraseologismen der wissenschaftlichen Fachsprache "Geschichte"/ Frazeologemi strokovnega jezika zgodovinske znanosti (Hudelja: 1997). Ker so pravi idiomatski izrazi v besedilni zvrsti 'znanstveni članek' relativno redko zastopani, so bili le-ti v glosar vključeni večinoma le takrat, ko gre za frazeološke termine, npr. Eiserner Vorhang/Železna zavesa in Dritte Welt/Tretji svet (vključevanje pravih idiomatskih izrazov splošnega jezika bi bilo glede na njihovo neprimerno večjo zastopanost npr. v besedilni zvrsti 'politični komentar' sicer vmesno, vendar bi preseglo okvire, ki smo si jih začrtali z izdajo našega glosarja). Pač pa smo v večji meri v glosar vključili delne idiomatske in neidiomatske izraze. Semkaj sodijo delni idiomatski izrazi s poimenovalno funkcijo (Auswärtiges Amt, Kalter Krieg, Erste Kammer), frazeološki termini (ethnische Säuberung, parlamentarische Hürden, stehendes Heer) in besedni pari (Hab und Gut, Grund und Boden, Jahr und Tag). Od neidiomatskih so vkljǔčne tiste frazeološke enote, ki jih Fleischer (1982) imenuje nominacijski stereotipi. Čeprav njihov pomen lahko ugotovimo na podlagi pomena posameznih slovarskih enot, pa se vendarle, četudi malenkostno, ločijo od navadnega seštevka le-teh. Značilen zanje je ustaljen besedni red. V zgodovinskem kontekstu se pogosto pojavljajo naslednji nominacijski stereotipi:

- besedni pari (Regierung und Opposition, Partei und Regierung)

- nominalni in verbalni klišeji, značilni zlasti za politični jezik (die breiten Massen, die öffentliche Meinung, im Mittelpunkt stehen)

- neidiomatske dvojice (Jahr und Tag, Haus und Hof, Hab und Gut)

- politična gesla (friedliche Koexistenz, internationale Pflicht der Kommunisten, vereinigtes Europa) 
Posebno skupino neidiomatskih izrazov v glosarju tvorijo tudi nekatere komunikativne formule, pomembne za razumevanje historičnega konteksta. Semkaj sodijo vljudnostne fraze v uradnih dopisih in privatni korespondenci (npr. Hochlöblicher Magistrat!/ Veleslavni magistrat!, Euer Woblgeboren!/Vaše blagorodje!, Hochachtungsvoll.../ Z odličnim spoštovanjem ...). V glosar so vključene tudi nekatere stalne predložne zveze (unter Ausschluss (der Öffentlichkeit), im Auftrag, aus Anlass)) ter številni funkcijski sklopi (eine Verbesserung erfabren, Maßnabmen treffen, unter Beschuß nebmen, Anklage erheben). Slednji so namreč pogosto rabljeni v pravnih in upravnih besedilnih vrstah (testament, poročna pogodba, prodajna pogodba, okrožnica, odredba, ukaz ...). Zato smo jih v velikem številu vključili v glosar. Pri določenih funkcijskih sklopih semantična povezava med samostalnikom in glagolom sicer ne povzroča težav pri dekodiranju (eine Antwort geben, eine Frage stellen, Angst haben), pri mnogih pa se pomen glagolov v takšni besedni zvezi loči od njihovega osnovnega pomena (Anklage erheben, Maßnabmen treffen, Folge leisten). Včasih pa je semantična povezava med verbalnim samostalnikom in glagolom, iz katerega je samostalnik izpeljan, popolnoma zabrisana (in Angriffnebmen, den Ausschlag geben, in Anspruch nebmen). Funkcijske sklope v prvi skupini bi lahko uvrstili med neidiomatske, tiste $\mathrm{v}$ drugi skupini med delne idiomatske, slednje pa med prave idiomatske izraze. K neidiomatskim izrazom bi lahlo prištevali tudi številne kolokacije s političnim oz. zgodovinskim pomenom (eine Verschwörung anzetteln/ anstiften, einen Aufstand unterdrücken/niederschlagen, ein Komplott schmieden), ki so prav tako v velikem številu vključene v glosar. Na splošno pa za naš glosar velja, da lahko prave idiomatske, delne idiomatske in neidiomatske izraze, ki imajo strokovni, torej historični pomen, prištevamo k osrednjemu delu zgodovinskega izrazja, ostale pa k njegovemu obrobju.

\section{ZGRADBA GESELSKEGA ČLANKA}

Geselski članek je sestavljen iz treh oz. dveh razdelkov: a) geselski besedi (ki je v krepkem tisku, če je geselska beseda t. i. citatna beseda, pa v krepkem ležečem tisku) lahko sledi b) pri samostalniku oznaka za spol in c) pomenski razdelek s slovenskimi ustrezniki. Sledeč načelu čim večje uporabne informativnosti posameznih gesel, sprejetih v glosar, je v pomenskem razdelku za slovenskimi ustrezniki v posameznih primerih naveden orientacijski podatek, ki je po svoji funkciji lahko a) dodatno pomensko pojasnilo (npr. bakalaureat (akademski naziv)), b) pri t. i. citatnih besedah navedba vira (oznaka zanj - s pripisano številko strani), iz katerega v glosar sprejeta beseda oz. njen predstavljeni pomen izhaja (npr. aasrecht (G. I. 380, G. II. 251)), c) z zvezdico označen starinski oz. zastarel izraz (npr. Anstalt (*naprava)), bodisi č) prav tako z zvezdico označen germanizem oz. avstriacizem (npr. Bafel (*pofl)). Sledijo relevantni primeri rabe, besedne zveze s funkcijskimi glagoli, kolokacije, frazeološke zveze ipd.

Pri predstavitvi geselske besede glosar opozarja na večpomenskost in na homonimijo, pri čemer so posamezni primeri pri večpomenski besedi v pomenskem razdelku med seboj ločeni s številkami, medtem ko so homonimi predstavljeni ločeno kot samostojna gesla (če sta samostalnika oz. če so samostalniki istega 
gramatikalnega spola, je homonimija dodatno označena s nadpisano številko takoj za geselsko besedo.

Poseben slovaropisni tip orientacijskega podatka, navedenega v oklepaju takoj za geselsko besedo, je slovarska kazalka: označena je s puščico, ki največkrat a) usmerja $\mathrm{k}$ sopomenki (Okzident $(\rightarrow$ Abendland)), b) napotuje $\mathrm{k}$ podpomenki (Lähmung ( $\rightarrow$ Lungenlähmung)), c) pri geslih, ki so izjemoma zapisana v starejši obliki ali narečni obliki, usmerja h geslu z novejšim zapisom (npr. Kaischler $(\rightarrow K e-$ uschler)), ̌́) izjemoma opozarja na množinsko obliko (npr. Bergmann ( $\rightarrow$ Bergleute)) ali pa d) v primeru funkcijskih sklopov - opozarja na samostalnike, ki nastopajo $\mathrm{v}$ zvezi z funkcijskimi glagoli, in napotuje k njim (npr. treffen ( $\rightarrow$ Maßnahme)).

Nekatera za slovensko zgodovino temeljna gesla so opremljena s kratko razlago. V glosar so uvrščeni tudi nazivi številnih strank, organizacij in društev, mestoma tudi njihove kratice ter besedne okrajšave. Mnoga lastnoimenska gesla so razširjena z določenimi stvarnimi podatki. Dodatek h glosarju prinaša stare zapise za mesece, nekatera osebna in pogosta zemljepisna imena.

\section{SKLEP}

Pričujoči Nemško-slovenski zgodovinski glosar je poskus pisanja glosarja na področju humanistike oz. družboslovja. Glosar izhaja iz bistva zgodovinske znanosti in njenega povezovanja s sorodnimi vedami. Zato je nabor gesel zasnovan širše in sega tudi na področje zgodovini sorodnih ved in splošnega jezika. V svojem bistvu predstavlja kompromisno rešitev, saj se je izkazalo, da pri naboru gesel ni smiselno uporabiti istih kriterijev, kot veljajo za terminologijo drugih, zlasti ekzaktnih znanosti (npr. dosledna enopomenskost, izključevanje sopomenskosti in konotativnosti). $\mathrm{V}$ določenem smislu glosar prehiteva razvoj dogodkov, saj bodo šele $z$ nastankom enojezičnega slovenskega zgodovinskega terminološkega slovarja ustvarjeni pogoji za poenotenje slovenskih ustreznic pri mnogih v slovar sprejetih geslih.

Zgoraj opisani pristop pri vključevanju gesel naj bi bil hkrati tudi prijazen do uporabnika. To načelo glosar zasleduje tudi v pomenskem razdelku z relevantnimi primeri rabe, kolokacijami, besednimi in frazeološkimi zvezami ter funkcijskimi sklopi, po drugi strani pa z dodatnimi podatki razlagalnega tipa, z navedbo vira pri t. i. citatnih besedah in dodatkom.

\section{BIBLIOGRAFIJA}

OSMAN, N. (1998) Kleines Lexikon untergegangener Wörter. München: Verlag. C.H.Beck

FLEISCHER, W. (1982) Phraseologie der deutschen Gegenwartssprache. Leipzig: VEB Bibliographisches Institut Leipzig

HUDELJA, N. (1997) Phraseologismen der wissenschaftlichen Fachsprache »Geschichte«. Filozofska fakulteta Univerze v Ljubljani (magistrsko delo) 
DUDEN (1999) Das große Wörterbuch der deutschen Sprache in 10 Bänden. Mannheim-Leipzig-Wien-Zürich: Dudenverlag

\section{POVZETEK}

\section{Nemško-slovenski zgodovinski glosar ali poskus pisanja glosarja na področju humanistike oz. družboslovja}

Avtor najprej umesti zgodovinsko znanost v okvir humanistike oz. družboslovja, ugotavlja njeno povezanost s pomožnimi vedami in sorodnimi disciplinami. Na podlagi tega opiše kriterije, ki so ga vodili pri naboru gesel za zgodovinski glosar. Ob tem se zavzema za kompromisno rešitev, torej tudi vključevanje polterminov in neterminoloških enot, saj je prepričan, da na zadevnem področju ni mogoče dosledno upoštevati tistih zakonitosti, ki sicer opredeljujejo terminologijo. Sledi opis v glosar vključenega izrazja, pri čemer loči med osrednjim in obrobnim delom zgodovinske terminologije. Takšna rešitev je po njegovem prepričanju tudi uporabniku prijazna rešitev.

Ključne besede: zgodovinski glosar, kriteriji za izbiro gesel, vključevanje polterminov in neterminoloških enot

\section{ABSTRACT \\ German-Slovene Historical Glossary or: An Attempt to Write a Glossary in the Field of Humanities or Social Sciences}

The author first defines the role of history as a constituent part of the humanities and the social sciences, explaining its connection with other, related scientific disciplines. On the basis of this, he presents the criteria of his selection of terms for the historical glossary. His preference is a compromising approach, which means inclusion of semi-terms and non-terms, since he believes that in the selected field of science it is impossible to consistently comply with the definition of terminology. The paper then discusses the entries in the glossary, distinguishing between the central and the peripheral part of historical terminology. The author is convinced that such an approach, in addition to its other advantages, is also very user-friendly.

Keywords: historical Glossary, selection of terms, inclusion of semi-terms and nonterms 